\title{
Evaluasi Pengolahan Air Limbah Domestik dengan IPAL Komunal di Kota Bogor
}

\section{Evaluation of Domestic Wastewater Treatment Using Communal WWTP in Bogor City}

\author{
DHAMA SUSANTHI ${ }^{*}$, MOH. YANUAR J. PURWANTO ${ }^{2}$, SUPRIHATIN ${ }^{3}$ \\ ${ }^{1 *}$ Program Studi Pengelolaan Sumberdaya Alam dan Lingkungan, Sekolah Pascasarjana, Institut Pertanian Bogor, \\ Kampus IPB Dramaga, Bogor 16680 \\ ${ }^{2}$ Departemen Teknik Sipil dan Lingkungan, Fakultas Teknologi Pertanian, Institut Pertanian Bogor \\ ${ }^{3}$ Departemen Teknologi Industri Pertanian, Fakultas Teknologi Pertanian, Institut Pertanian Bogor \\ dhama_2105@apps.ipb.ac.id
}

\begin{abstract}
One of domestic wastewater treatment in Bogor City is by using communal WWTP (Wastewater Treatment Plant) system. The communal WWTP treats domestic wastewater with an anaerobic baffled reactor configuration $(A B R)$. This study aims to determine the effluent quality of communal WWTP so that it can be used as reference for related institutions in managing communal WWTP. The effluent from 3 communal WWTPs namely KSM Amanah, Rosella, and Cipendek Indah measured the content of TSS, $C O D$, oil and grease, ammonia, and total coliform. The secondary data of effluent from 40 communal WWTP were obtained from Environment Agency of Bogor City. The result of the effluent analysis is compared with the Minister of Environment and Forestry Regulation No. P.68/2016 on the Quality Standard of Domestic Wastewater. The study showed that the total coliform parameter did not meet the quality standard in 3 communal WWTP locations, COD exceeded the quality standard in KSM Rosella and Cipendek Indah, and TSS above the quality standard in KSM Cipendek Indah. The communal WWTP in Bogor city has not been effective in reducing the pollutant content in domestic wastewater especially BOD and total coliform. The communal WWTP management needs to be improved in order for better effluent.
\end{abstract}

Keywords: domestic waste, communal WWTP, effluent, quality standard, bogor city

\begin{abstract}
ABSTRAK
Salah satu pengolahan air limbah domestik di Kota Bogor yaitu menggunakan sistem IPAL komunal. IPAL komunal mengolah air limbah domestik dengan konfigurasi anaerobic baffled reactor (ABR). Penelitian ini bertujuan untuk mengetahui kualitas efluen IPAL komunal di Kota Bogor sehingga dapat dijadikan acuan bagi instansi terkait dalam mengelola IPAL komunal. Efluen dari 3 IPAL komunal yaitu KSM Amanah, Rosella, dan Cipendek Indah diukur kandungan TSS, COD, minyak lemak, amonia, dan total coliform. Data sekunder efluen dari 40 IPAL komunal diperoleh dari Dinas Lingkungan Hidup Kota Bogor. Hasil analisis efluen tersebut dibandingkan dengan baku mutu PermenLHK No. P.68/2016 tentang Baku Mutu Air Limbah Domestik. Penelitian menunjukkan bahwa parameter total coliform tidak memenuhi baku mutu di 3 lokasi IPAL komunal yang diteliti, COD melebihi baku mutu di KSM Rosella dan Cipendek Indah, serta TSS diatas baku mutu teridentifikasi di KSM Cipendek Indah. IPAL komunal di Kota Bogor belum efektif dalam menurunkan kandungan polutan dalam air limbah domestik terutama BOD dan total coliform. Pengelolaan IPAL komunal perlu ditingkatkan agar kualitas efluen yang dihasilkan lebih baik.
\end{abstract}

Kata kunci: limbah domestik, IPAL komunal, efluen, baku mutu, kota bogor

\section{PENDAHULUAN}

\subsection{Latar Belakang}

Air limbah domestik menjadi polutan terbesar yang masuk ke perairan dan berkontribusi dalam meningkatkan pencemaran ${ }^{(1,2,3)}$. Hal ini dikarenakan $60-80 \%$ dari air bersih yang digunakan akan dibuang ke lingkungan sebagai air limbah ${ }^{(4)}$. Hasil analisis statistik secara nasional menunjukkan sebanyak $62,14 \%$ rumah tangga telah memiliki akses terhadap sanitasi layak ${ }^{(5)}$, akan tetapi proporsi rumah tangga yang masih membuang air limbah domestik ke got/saluran drainase mencapai $46,7 \%{ }^{(6)}$. Proporsi warga Kota Bogor yang mengalirkan air limbah domestik ke sungai dan 
saluran terbuka juga masih tinggi mencapai $60,24 \%(7)$. Berdasarkan buku putih sanitasi Kota Bogor tahun 2014, permasalahan sub sektor air limbah domestik masih menjadi permasalahan yang mendominasi di seluruh kelurahan di Kota Bogor $^{(8)}$. Sebagai upaya menekan pencemaran lingkungan yang disebabkan air limbah domestik, sampai dengan tahun 2015 tercatat 52 unit IPAL komunal (sistem on site) telah dibangun di Kota Bogor. Pembangunan IPAL komunal diharapkan dapat mengurangi 60\% beban polusi di lingkungan dari 17 ton BOD menjadi 8 ton BOD pada tahun $2030^{(9)}$.

Teknologi pengelolaan air limbah domestik di kawasan perkotaan yang secara luas diterapkan di Indonesia yaitu decentralized wastewater treatment systems (DEWATS) melalui program sanimas (sanitasi berbasis masyarakat)(10). Penerapan sanitasi berbasis masyarakat di Kota Bogor sudah terealisasi dengan dibangunnya instalasi pengolahan air limbah (IPAL) komunal. Seluruh IPAL komunal di Kota Bogor menggunakan konfigurasi anaerobic baffle reactor (ABR) sebagai unit

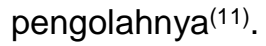

Pengolahan air limbah dengan ABR sangat cocok untuk negara tropis seperti Indonesia yang suhunya tinggi hampir setiap waktu dan kondisinya mendukung untuk proses anaerobik $^{(12)}$. Konfigurasi ABR diketahui relatif stabil terhadap tekanan hidraulik dan kondisi dimana terjadi pemasukan bahan organik secara mendadak ${ }^{(13)}$. Berdasarkan hasil penelitian diketahui bahwa teknologi ABR mampu menurunkan parameter air limbah (BOD, TSS, minyak dan lemak) dengan efektifitas yang tinggi(14). ABR dapat secara efektif menurunkan kadar TSS sampai 91\%, BOD dapat diturunkan sampai $78 \%$, dan kadar COD dapat turun mencapai $77 \%{ }^{(15)}$.

IPAL komunal terbangun tidak selamanya mempunyai kinerja yang optimal dalam menurunkan kadar polutan air limbah domestik. Penelitian menunjukkan bahwa masih terdapat beberapa parameter efluen IPAL komunal yang tidak memenuhi baku mutu(16). Air limbah domestik yang tidak memenuhi baku mutu tersebut apabila dibuang ke lingkungan dapat menambah beban pencemaran. Sebagai upaya pengendalian pencemaran, kualitas efluen IPAL komunal dipantau setiap satu tahun sekali oleh Dinas Lingkungan Hidup Kota Bogor. Efluen yang dipantau sebanyak 40 efluen dari total 52 IPAL komunal yang terbangun. Pemantuan efluen ini hanya berhenti pada hasil uji kualitas air limbah yang memenuhi baku mutu atau tidak memenuhi baku mutu, belum disertai dengan perbaikan pengolahan di lapangan.

Secara umum efluen dari IPAL komunal di Kota Bogor dibuang ke perairan sungai dan saluran drainase lainnya serta belum dimanfaatkan kembali (reuse). Evaluasi pengolahan air limbah domestik dari IPAL komunal diharapkan dapat menjadi masukan untuk optimalisasi pengolahan IPAL komunal sehingga menghasilkan kualitas efluen yang lebih baik.

\subsection{Tujuan Penelitian}

Tujuan dari penelitian ini adalah mengetahui kualitas air buangan (efluen) hasil pengolahan IPAL komunal di Kota Bogor.

\section{BAHAN DAN METODE}

\subsection{Bahan}

Sampel air limbah dari efluen IPAL komunal diambil secara langsung (grab sampling) dan merujuk kepada Peraturan Menteri Negara Lingkungan Hidup No. 01 Tahun 2010 tentang Tata Laksana Pengendalian Pencemaran Air ${ }^{(17)}$. Sampel air limbah diambil dengan menggunakan gayung, selanjutnya dimasukkan ke dalam 3 jenis botol polietilen/ gelas sesuai dengan jenis parameter disertai preservasi untuk kepentingan analisis laboratorium. Cara pengawetan dan penyimpanan sampel efluen air limbah domestik disesuaikan dengan SNI 6989.57:2008.

\subsection{Metode}

Penelitian dilakukan pada bulan November 2017 sampai dengan Januari 2018, dengan mengambil sampel air limbah sebanyak 6 sampel dari 3 efluen IPAL komunal (setiap lokasi dilakukan pengambilan sampel sebanyak dua kali pada jam yang sama dan hari yang berbeda). Lokasi IPAL komunal tersebut adalah IPAL komunal dan MCK++ dari Kelompok Swadaya Masyarakat/ KSM Amanah (Kelurahan Sindangsari, Kecamatan Bogor Timur), KSM Rosella (Kelurahan Pamoyanan, Kecamatan Bogor Selatan), dan KSM Cipendek Indah (Kelurahan Bubulak, Kecamatan Bogor Barat). Koordinat lokasi IPAL komunal disampaikan pada Tabel 1. Ketiga lokasi IPAL komunal dipilih karena telah beroperasi selama 5 tahun atau lebih.

Tabel 1. Koordinat lokasi IPAL Komunal yang diteliti

\begin{tabular}{lcc}
\hline \multirow{2}{*}{ Nama Lokasi IPAL } & \multicolumn{2}{c}{ Koordinat } \\
\cline { 2 - 3 } & $\begin{array}{c}\text { Lintang } \\
\text { Selatan }\end{array}$ & $\begin{array}{c}\text { Bujur } \\
\text { Timur }\end{array}$ \\
\hline KSM Amanah & $06^{\circ} 39^{\prime} 07.44^{\prime \prime}$ & $106^{\circ} 50^{\prime} 48.15^{\prime \prime}$ \\
KSM Rosella & $06^{\circ} 38^{\prime} 13.93^{\prime \prime}$ & $106^{\circ} 48^{\prime} 27.18^{\prime \prime}$ \\
$\begin{array}{l}\text { KSM Cipendek } \\
\text { Indah }\end{array}$ & $06^{\circ} 33^{\prime} 49.91^{\prime \prime}$ & $106^{\circ} 45^{\prime} 13.0^{\prime \prime}$ \\
\hline
\end{tabular}

Parameter yang diukur yaitu parameter fisik (TSS), kimia (COD, minyak lemak, amonia), dan 
biologi (total coliform). Analisis efluen dilakukan di Laboratorium Proling, Institut Pertanian Bogor. Parameter tersebut selanjutnya dibandingkan dengan Peraturan Menteri Lingkungan Hidup dan Kehutanan RI No.P.68 Tahun 2016 tentang Baku Mutu Air Limbah Domestik, Lampiran I Baku Mutu Air Limbah Domestik Tersendiri(18). Data sekunder hasil analisis 40 efluen IPAL komunal didapatkan dari Laporan Akhir Pengujian Kualitas Air Limbah Sanimas Tahun 2016 dan 2017 oleh Dinas Lingkungan Hidup Kota Bogor(19,20). Gambaran pengambilan sampel efluen dapat dilihat pada Gambar 1, sedangkan skema tipikal IPAL komunal yang menjadi objek penelitian seperti Gambar 2.

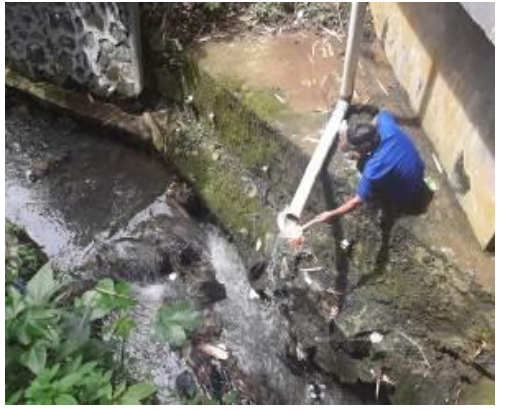

(a) KSM Amanah

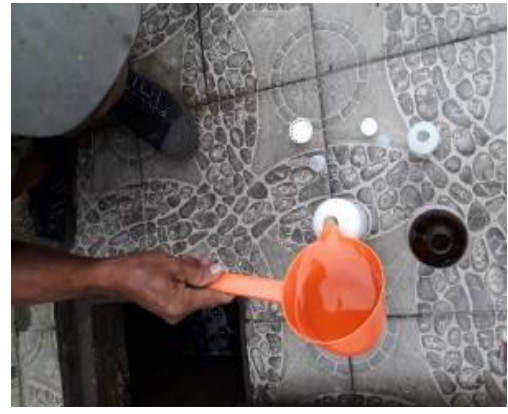

(b) KSM Rosella

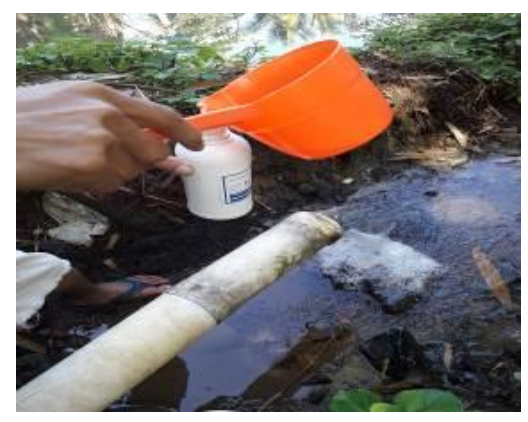

(c) KSM Cipendek Indah

Gambar 1. Pengambilan sampel air limbah dari efluen IPAL komunal

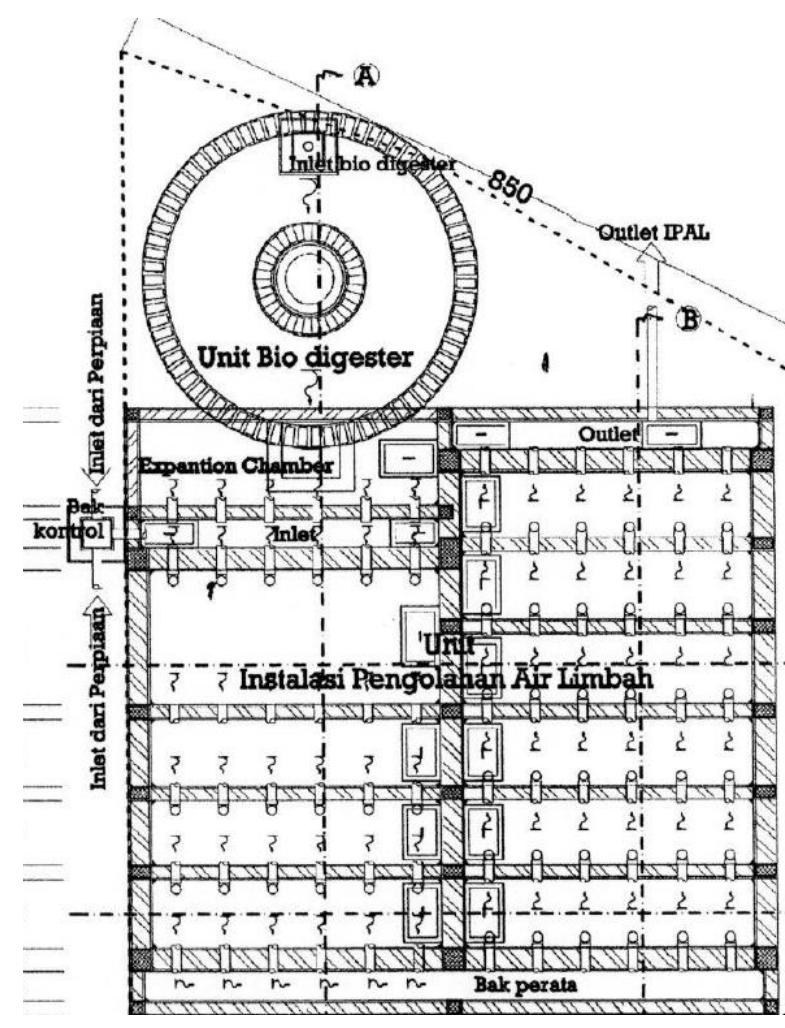

Gambar 2. Skema IPAL komunal dengan biodigester di Kota Bogor ${ }^{(21)}$

\section{HASIL DAN PEMBAHASAN}

Unit-unit yang digunakan dalam sistem IPAL komunal dan $\mathrm{MCK}++$ di Kota Bogor adalah biodigester, expansion chamber, bak perata (settler), dan kompartemen anaerobic baffled reactor (Gambar 2). Secara umum proses pengolahan air limbah dari IPAL komunal dan
MCK++ sebagai berikut: (1) air limbah domestik dan tinja mengalir ke bak influen, kemudian di proses pada bak digester, (2) limpahan air dari bak digester dialirkan ke bak pelimpah yang juga sebagai influen grey water, (3) air limbah dari bak pelimpah kemudian dialirkan melalui bak settler sebagai bak sedimentasi, (4) setelah melalui bak sedimentasi maka air limbah difiltrasi menggunakan bakteri pada bak baffle reactor, (5) hasil filtrasi dari bak baffle reactor masuk ke bak outlet untuk dibuang ${ }^{(22)}$.

\subsection{Parameter Total Suspended Solid (TSS)}

Tingginya konsentrasi TSS yang dibuang ke perairan akan mempengaruhi penetrasi cahaya sehingga mengganggu proses fotosintesis(23). TSS merupakan padatan yang mengakibatkan kekeruhan air, tidak terlarut dan tidak dapat mengendap langsung, seperti bahan organik yang terkandung dalam air limbah(24). Bahan organik yang dimaksud terdiri dari berbagai jenis senyawa seperti selulosa, lemak, protein atau dapat juga berupa mikroorganisme(25).

Hasil analisis terhadap TSS menunjukkan bahwa hanya efluen dari IPAL KSM Cipendek Indah yang melebihi baku mutu PermenLHK No. P.68 tahun 2016. Akan tetapi berdasarkan analisis DLH tahun 2016, TSS dari efluen KSM Rosella dan Cipendek Indah melebihi baku mutu. Pengukuran yang dilakukan kembali oleh DLH tahun 2017 menunjukkan bahwa TSS dari 3 IPAL komunal tersebut semuanya melebihi baku mutu (Gambar 3). Hal ini menunjukkan bahwa kandungan TSS pada efluen IPAL komunal fluktuatif. 
Berdasarkan Gambar 4 dapat diketahui rata-rata kandungan TSS dari 40 efluen IPAL komunal di Kota Bogor memenuhi baku mutu, hanya sekitar 8 lokasi IPAL yang tidak memenuhi baku mutu. Penurunan kandungan TSS dipengaruhi oleh lama waktu kontak air limbah dengan mikoorganisme yang terdapat di dalam kompartemen IPAL. Semakin lama waktu kontak maka efisiensi penurunan TSS akan meningkat ${ }^{(26)}$. Hal ini dikarenakan terjadi biokonversi secara enzimatis dan aktivitas asidogenesis oleh mikroorganisme(27).

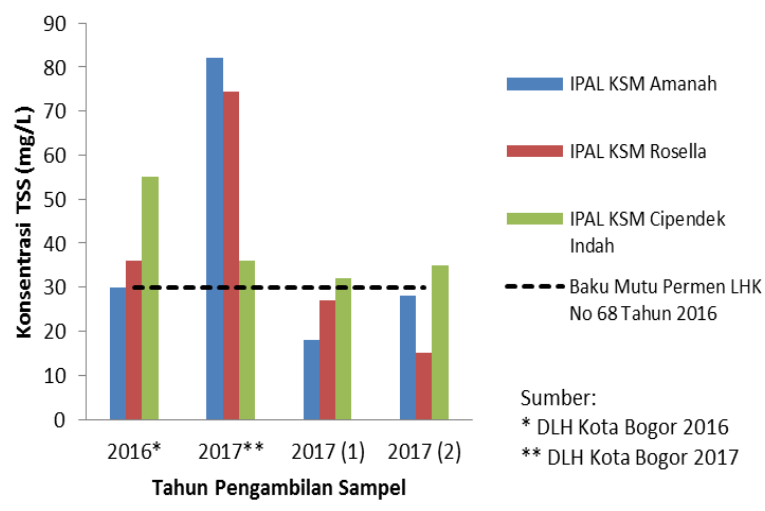

Gambar 3. Perbandingan parameter TSS pada 3 efluen IPAL komunal

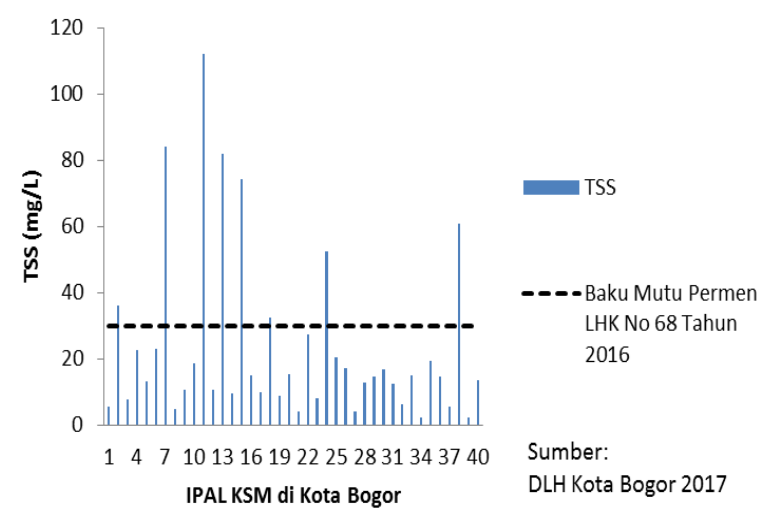

Gambar 4. Kandungan TSS pada 40 efluen IPAL komunal di Kota Bogor tahun 2017

\subsection{Parameter $\mathrm{pH}$}

Nilai $\mathrm{pH}$ diperoleh dari hasil pengukuran yang dilakukan oleh DLH Kota Bogor tahun 2016 dan 2017 (Gambar 5). Hasil pengukuran di 3 lokasi IPAL (KSM Amanah, Rosella, dan Cipendek Indah) pada tahun 2016 dan 2017 menunjukkan bahwa nilai $\mathrm{pH}$ efluen KSM Rosella tahun 2017 tidak memenuhi baku mutu. Efluen IPAL KSM Rosella pada pengukuran tahun 2017 menunjukkan pH dibawah baku mutu sekitar 5,73. Hasil analisis terhadap efluen dari 40 IPAL komunal pada tahun 2017 terdapat 4 lokasi IPAL komunal dengan nilai $\mathrm{pH}$ yang nilainya dibawah baku mutu $(\mathrm{pH}<6)$. Hasil pengukuran $\mathrm{pH}$ dari 40 IPAL komunal seperti pada Gambar 6. Sesuai dengan PermenLHK No. P.68 tahun 2016, nilai pH dari air limbah domestik yang dibuang ke lingkungan harus memenuhi baku mutu dengan kisaran antara 6 sampai 9.

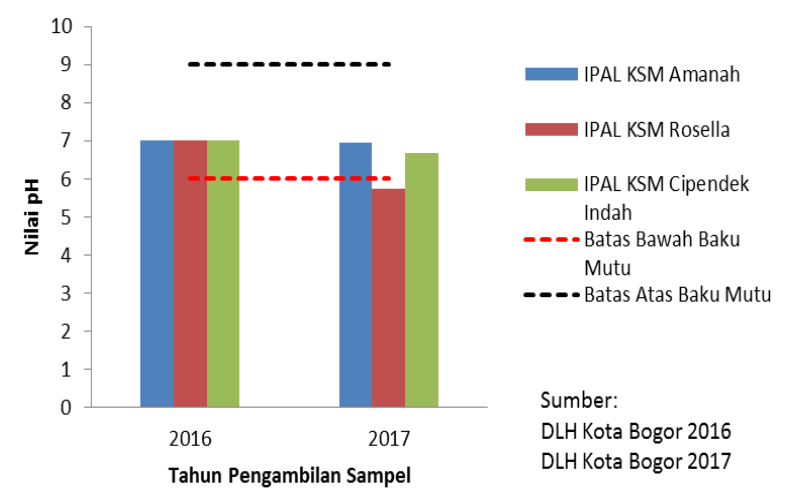

Gambar 5. Perbandingan nilai $\mathrm{pH}$ pada 3 efluen IPAL komunal

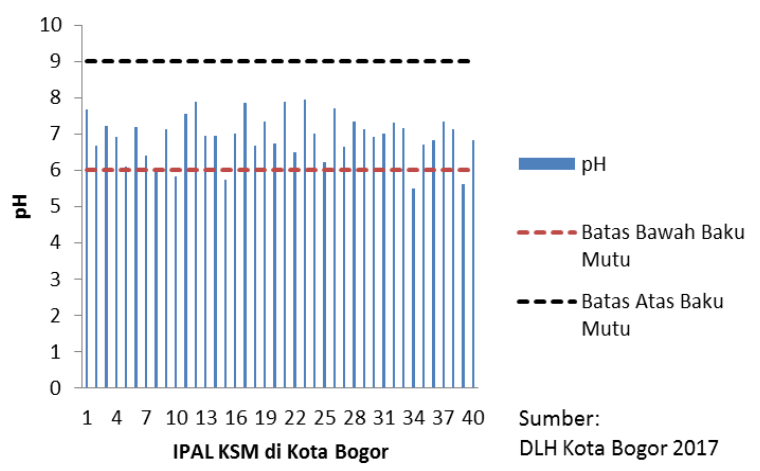

Gambar 6. Hasil pengukuran pH pada 40 efluen IPAL komunal di Kota Bogor tahun 2017

Proses pengolahan biologis secara anaerob di dalam sistem ABR membutuhkan bantuan mikroorganisme anaerob yang prosesnya dipengaruhi oleh $\mathrm{pH}$ dan temperatur lingkungan(3,28). Polutan organik dalam air limbah akan diuraikan oleh bakteri anaerob melalui reaksi biokimia menjadi gas metana $\left(\mathrm{CH}_{4}\right)$ dan gas karbon dioksida $\left(\mathrm{CO}_{2}\right)^{(29,30,31)}$. Bakteri yang berperan dalam proses anaerob ini terdiri dari dua jenis yaitu bakteri asidogenesis (pembentuk asam) dan metanogenesis. Efluen IPAL komunal dengan nilai $\mathrm{pH}$ yang rendah kemungkinan disebabkan adanya aktifitas bakteri asetogenesis yang merubah senyawa organik dihidrolisa menjadi senyawa yang lebih sederhana(2).

Nilai pH dibawah 6 akan mempengaruhi aktivitas bakteri metanogenik dan apabila nilai pH 5,5 akan mengakibatkan terhentinya aktifitas bakteri(32). Terhentinya aktifitas bakteri metanogenik juga akan mempengaruhi biogas yang dihasilkan. Ketiga lokasi IPAL komunal merupakan IPAL komunal yang memiliki fasilitas 
tambahan berupa biodigester untuk menghasilkan biogas. Hasil biogas dari IPAL KSM Amanah dimanfaatkan untuk memenuhi kebutuhan gas 1 rumah tangga, sedangkan KSM Rosella memanfaatkan biogas untuk kepentingan pendukung usaha 1 pesantren. Biogas dari IPAL KSM Cipendek Indah tidak bisa dimanfaatkan karena adanya kerusakan. Biogas yang dihasilkan IPAL KSM Rosella cenderung sedikit, kemungkinan disebabkan aktifitas bakteri tidak optimal pada $\mathrm{pH}$ rendah (nilai pH 5,73).

\subsection{Parameter Chemical Oxygen Demand (COD)}

Chemical oxygen demand (COD) adalah jumlah oksigen total yang dibutuhkan untuk mengoksidasi bahan organik secara kimiawi(33), dan lebih banyak digunakan sebagai parameter untuk mengetahui banyaknya bahan organik dalam suatu sistem ${ }^{(34)}$. Pengukuran COD pada tahun 2017 oleh DLH Kota Bogor terhadap 40 efluen IPAL komunal menunjukkan bahwa nilai COD berkisar antara 32,7 mg/l sampai 94,2 $\mathrm{mg} / \mathrm{l}$, berarti semuanya masih memenuhi baku mutu (Gambar 7). Hasil analisis COD pada efluen IPAL KSM Rosella menunjukkan hasil yang melebihi baku mutu (Gambar 8). Nilai COD yang tinggi tersebut dapat mengindikasikan kinerja mikroorganisme pengurai di dalam sistem yang belum efektif.

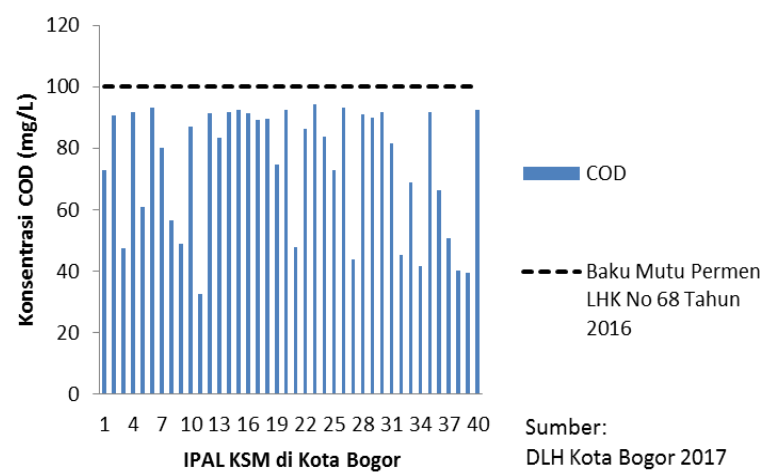

Gambar 7. Nilai COD pada 40 IPAL komunal di Kota Bogor tahun 2017

Pada saat kandungan bahan organik yang tinggi masuk ke dalam IPAL, mikroorganisme mengalami kejenuhan dan kematian sehingga materi organik tidak terurai yang ditunjukkan dengan meningkatkan nilai COD(34). Kemungkinan yang lainnya adalah waktu tinggal, karena semakin panjang waktu tinggal hidraulik maka akan semakin besar penyisihan COD dan sebaliknya jika waktu tinggal pendek maka penyisihan tidak optimal(35).

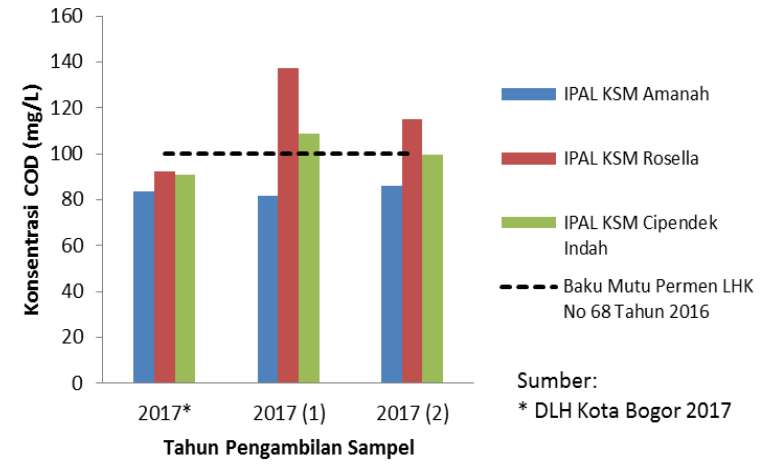

Gambar 8. Perbandingan nilai COD pada 3 efluen IPAL komunal

\subsection{Parameter Biochemical Oxygen Demand (BOD)}

Secara umum nilai BOD air limbah domestik hasil olahan IPAL komunal di Kota Bogor masih diatas $30 \mathrm{mg} / \mathrm{l}$ (Gambar 9). Nilai BOD IPAL KSM Amanah, Rosella, dan Cipendek Indah pada pengukuran tahun 2016 sudah sesuai dengan standar baku mutu PerMenLH No. 5 Tahun 2014 tentang Baku Mutu Air Limbah walaupun karena baku mutu yang menjadi acuan $100 \mathrm{mg} / \mathrm{l}$. Baku mutu berdasarkan PermenLHK No. P.68 Tahun 2016 lebih ketat yaitu $30 \mathrm{mg} / \mathrm{l}$, sehingga pada tahun 2017 semua efluen tergolong melebihi baku mutu. Nilai BOD dari IPAL Amanah, Rosella, dan Cipendek Indah secara berturut-turut yaitu 38 mg/l, 45,3 mg/l, dan 39,4 mg/l (Gambar 10).

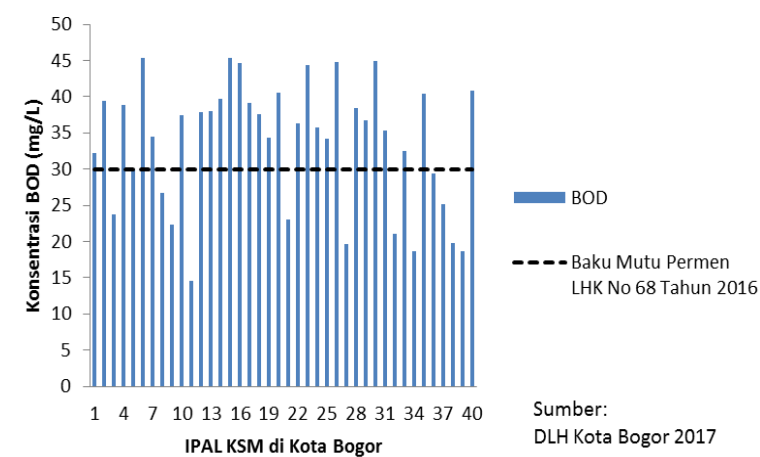

Gambar 9. Konsentrasi BOD pada 40 IPAL komunal di Kota Bogor tahun 2017

BOD (Biochemical oxygen demand) merupakan jumlah oksigen terlarut yang dibutuhkan mikoorganisme untuk menguraikan bahan organik dalam air(33). Tingginya kadar BOD pada efluen IPAL komunal disebabkan oleh tingginya kandungan bahan-bahan organik yang masuk ke dalam sistem IPAL, akan tetapi tidak diimbangi dengan proses pengolahan air limbah yang memadai(36). Selain itu debit air limbah juga mempengaruhi kemampuan IPAL dalam menurunkan BOD, semakin besar debit air limbah maka penurunan BOD semakin menurun $^{(2)}$. 


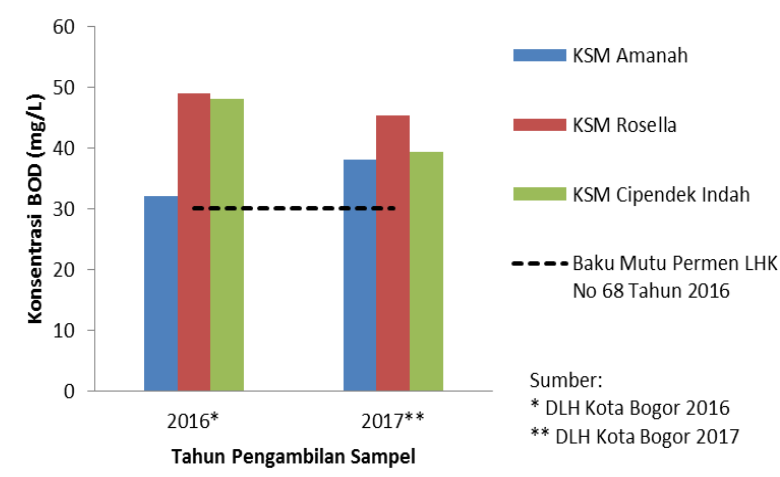

Gambar 10. Perbandingan parameter BOD pada 3 efluen IPAL komunal

\subsection{Parameter Amonia}

Amonia merupakan ciri khas dari penguraian limbah domestik yang mengandung nitrogen seperti pada tinja dan urin ${ }^{(37)}$. Kandungan amonia yang tinggi pada limbah domestik menjadi faktor kunci yang menyebabkan eutrofikasi pada badan air penerima. Amonia dapat bersifat toksik bagi organisme perairan pada konsentrasi $1 \mathrm{mg} / \mathrm{l}$ karena dapat mengurangi kapasitas oksigen di dalam air(38). Oleh karena itu hasil olahan air limbah domestik yang masuk ke perairan harus memenuhi baku mutu supaya tidak berdampak negatif terhadap lingkungan.

Kandungan amonia pada efluen 3 IPAL komunal memenuhi baku mutu, kecuali pada saat pengukuran pertama di KSM Rosella yang melebihi baku mutu (Gambar 11). Hasil pemantauan yang dilakukan oleh DLH Kota Bogor tahun 2017 juga menunjukkan bahwa efluen dari 40 lokasi IPAL komunal memenuhi baku mutu dengan kandungan amonia berkisar 0,023 mg/l sampai 4,56 mg/l (Gambar 12).

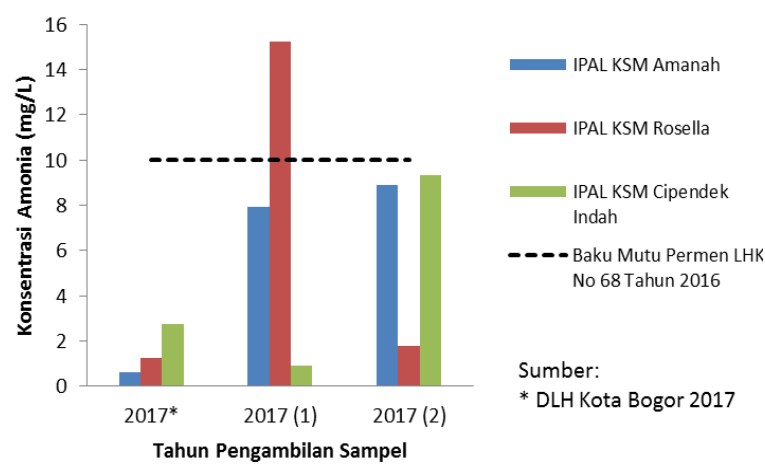

Gambar 11. Perbandingan parameter amonia pada 3 efluen IPAL komunal

Kemampuan IPAL dalam menurunkan amonia dipengaruhi antara lain oleh debit aliran limbah dan waktu tinggal(39). Semakin besar debit air limbah yang masuk kedalam sistem pengolahan IPAL maka akan semakin kecil penurunan kadar amonia, sedangkan semakin lama waktu tinggal maka efektifitas penurunan amonia semakin tinggi. Kandungan amonia didalam air limbah domestik dapat turun setelah melalui pengolahan pada kompartemen IPAL karena adanya aktivitas mikroorganisme yang dapat menguraikan amonia dalam air limbah menjadi nitrit atau nitrat melalui reaksi nitrifikasi(40).

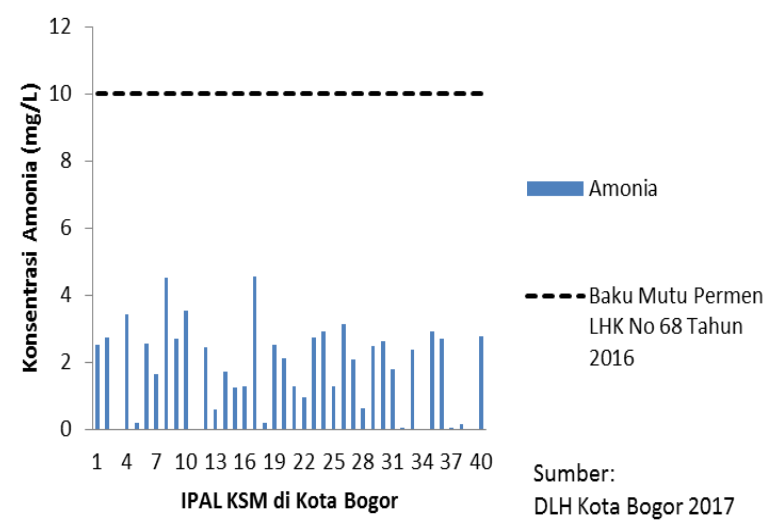

Gambar 12. Konsentrasi amonia pada 40 IPAL komunal di Kota Bogor tahun 2017

\subsection{Parameter Minyak Lemak}

Kandungan minyak dan lemak untuk semua efluen IPAL komunal memenuhi baku mutu, dengan rata-rata kandungan minyak dan lemak $<1 \mathrm{mg} / \mathrm{l}$. Efluen dari IPAL KSM Rosella menunjukkan nilai yang lebih tinggi dibandingkan dengan IPAL lainnya, akan tetapi masih memenuhi baku mutu (Gambar 13). Kandungan minyak dan lemak yang cukup tinggi pada air limbah domestik dapat mempengaruhi aktifitas mikroorganisme dalam mendegradasi limbah(41).

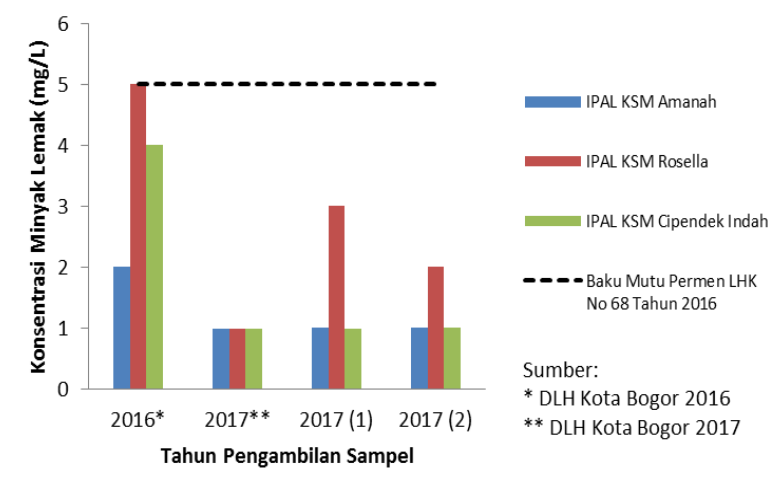

Gambar 13. Perbandingan parameter minyak lemak pada 3 efluen IPAL komunal

\subsection{Parameter Total Coliform}

Hasil analisis terhadap total coliform dari 40 efluen IPAL komunal yang beroperasi di Kota Bogor menunjukkan bahwa secara umum memenuhi baku mutu dan hanya 4 lokasi yang tidak memenuhi baku mutu seperti yang dapat dilihat pada Gambar 14. Pengukuran yang 
dilakukan pada 3 efluen IPAL komunal (Amanah, Rosella, dan Cipendek Indah) mengindikasikan bahwa semua efluen melebihi baku mutu. Hal ini terkait dengan sistem IPAL yang mengolah air limbah domestik dan tinja sehingga kemungkinan masih terjadi kontaminasi tinja sangat besar. Pada dasarnya pengelolaan dan pemeliharaan IPAL sangat mempengaruhi kemampuannya dalam mengurangi kandungan total coliform. Tingginya total coliform pada efluen dapat disebabkan pengendapan lumpur tinja di bak outlet yang tidak pernah dilakukan pengurasan ${ }^{(16)}$. Tingginya total coliform yang dibuang ke lingkungan dapat menimbulkan masalah bagi kesehatan masyarakat. Salah satu jenis bakteri coliform seperti Escherichia coli dapat menyebabkan gangguan kesehatan seperti tifus, kolera, hepatitis, dan diare apabila masuk ke dalam sistem pencernaan melalui minuman atau makanan ${ }^{(42)}$.

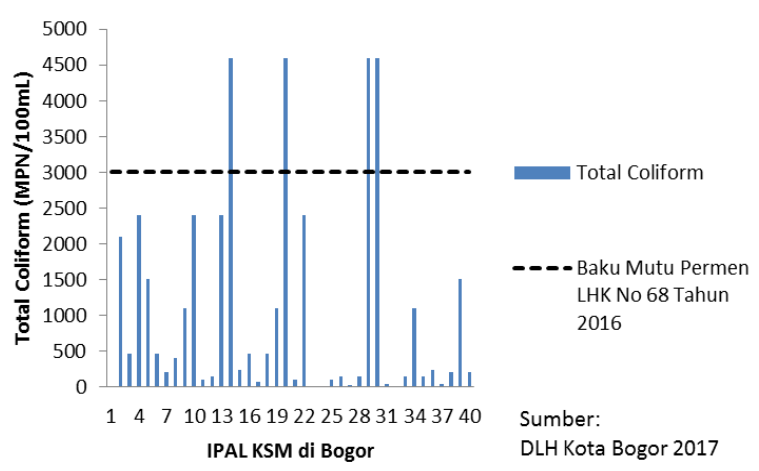

Gambar 14. Kandungan total coliform pada 40 efluen IPAL komunal di Kota Bogor tahun 2017

IPAL komunal KSM Amanah, Rosella, dan Cipendek Indah merupakan IPAL komunal yang dibangun sekitar tahun 2010 - 2013. IPAL KSM Amanah dan Rosella pernah dilakukan 1 kali penyedotan tinja sedangkan IPAL Cipendek Indah belum pernah dilakukan penyedotan. Kemampuan menurunkan kadar polutan dalam air limbah domestik sangat dipengaruhi oleh efektifitas dari penguraian biologis secara anaerobik. Efektifitas penguraian biologis dapat ditingkatkan dengan pengelolaan fasilitas IPAL sesuai dengan fungsinya.

Kinerja IPAL komunal yang sudah beroperasi saat ini perlu ditingkatkan kembali agar kualitas efluen menjadi lebih baik yaitu dengan pengelolaan IPAL sesuai prosedur dan fungsinya. Selain itu efluen yang dihasilkan dari proses pengolahan IPAL komunal masih memerlukan pasca pengolahan lanjutan supaya memenuhi kriteria guna ulang air limbah (reuse). Upaya yang dapat dilakukan dalam rangka meningkatkan kinerja IPAL komunal yang sudah terbangun di Kota Bogor antara lain:
- Pengurasan secara berkala (bak settler 2 tahun sekali, bak baffled reactor 3 tahun sekali) untuk meningkatkan kinerja proses anaerobik oleh mikroorganisme di dalam kompartemen ABR.

- Outlet air limbah dari rumah tangga perlu ditambah dengan grease trap (penjebak lemak) supaya minyak dan lemak yang masuk ke IPAL menjadi minimal.

- Penyedotan lumpur tinja dalam biodigester setiap 2 tahun sekali sehingga tinja tidak mengendap didalam bak outlet.

- Pipa pembuangan efluen ditambah dengan penyaring sederhana supaya menghasilkan TSS yang rendah.

- Meningkatkan durasi pemeliharaan jaringan perpipaan dan bak kontrol seperti membersihkan kotoran atau penyumbatan.

\section{KESIMPULAN}

Beberapa parameter efluen dari IPAL komunal yang telah beroperasi di Kota Bogor teridentifikasi melebihi baku mutu Peraturan Menteri Lingkungan Hidup dan Kehutanan RI No.P.68 Tahun 2016 tentang Baku Mutu Air Limbah Domestik. Sebagai upaya meningkatkan kualitas efluen maka diperlukan optimalisasi pengelolaan fasilitas IPAL komunal.

\section{PERSANTUNAN}

Penulis menyampaikan terima kasih kepada EOS Consultants pt. atas bantuan biaya penelitian. Penghargaan yang tinggi penulis sampaikan kepada ketua KSM Amanah, ketua KSM Cipendek Indah, KSM Rosella dan Ketua AKSANSI Kota Bogor. Ucapan terima kasih juga disampaikan kepada Dinas Lingkungan Hidup Kota Bogor (Bidang Pengendalian Pencemaran Lingkungan, Konservasi, dan Perubahan Iklim), Bappeda (Bidang Fisik dan Prasarana), Dinas PUPR (Bidang Air Minum dan Air Limbah), dan Dinas Kesehatan (Bidang Penyehatan Lingkungan) atas dukungan data-data serta diskusi selama penelitian.

\section{DAFTAR PUSTAKA}

1. Katukiza, A.Y., Ronteltap, M., Niwagaba, C.B., Foppen, J.W.A., Kansiime, F., \& Lens, P.N.L. (2012). Sustainable sanitation technology options for urban slums. Biotechnology Advances, 30(2012), 964978.

2. Yazid, F.R., Syafrudin, \& Samudro, G. (2012). Pengaruh variasi konsentrasi dan debit pada pengolahan air artificial (campuran grey water dan black water) 
menggunakan reaktor UASB. Jurnal Presipitasi, 9(1), 32-43.

3. Amri, K., \& Wesen, P. (2015). Pengolahan air limbah domestik menggunakan biofilter anaerob bermedia plastik (bioball). Jurnal IImiah Teknik Lingkungan, 7(2), 55-66.

4. Astika, A.U.W., Sudarno, \& Zaman, B. (2017). Kajian kinerja bak settler, anaerobic baffled reactor (abr), dan anaerobic filter (af) pada tiga tipe IPAL di Semarang. Jurnal Teknik Lingkungan, 6(1), 1-15.

5. Badan Pusat Statistik. (2016). Statistik Indonesia 2016. Jakarta: Badan Pusat Statistik.

6. Badan Penelitian dan Pengembangan Kesehatan. (2013). Riset kesehatan dasar (RISKESDAS) 2013. Jakarta: Kementerian Kesehatan.

7. Badan Perencanaan Pembangunan Daerah Kota Bogor. (2014). Laporan Survey Penilaian Resiko Kesehatan Lingkungan Environmental Health Risk Assessment (EHRA) Kota Bogor 2014. Bogor: Bappeda.

8. Badan Perencanaan Pembangunan Daerah Kota Bogor. (2014). Buku Putih Sanitasi Kota Bogor 2014. Bogor: Bappeda.

9. Indonesia Infrastructure Initiative. (2011). Rencana Induk Investasi Air Limbah Paket I: Bogor final Master Plan. Bogor: Bappeda.

10. Prihandrijanti, M., \& Firdayati, M. (2011). Current situation and consideration of domestic wastewater treatment system for big cities in Indonesia (case study : Surabaya and Bandung). Journal of Water Sustainability, 1(2), 97-104.

11. Kusumadewi, A.A., \& Handajani, M. (2013). Evaluasi kerja sanimas di Kota Bogor (studi kasus: kelurahan Tajur dan Harjasari). Retrieved from: http://publikasi.ftsl.itb.ac.id/ assets/repositori/2013_10_19/2/1_2_153090 62_berkas.pdf.

12. Ramandeep, K. (2016). Anaerobic baffled reactor: apromising wastewater treatment technology in tropical countries. International Journal on Emerging Technologies (Special Issue on RTIESTM-2016), 7(1), 114-117.

13. Mousavi, N., Najafpour, G.D., Bakhshi, Z., \& Pishgar, R. (2011). Performance of anaerobic baffled reactor for biodegradation of phenol. Iranica J. Energy \& Environ, 2(3), 229-234.

14. Afandi, Y.V., Sunoko, H.R., \& Kismartini. (2013). Status keberlanjutan sistem pengelolaan air limbah domestik komunal berbasis masyarakat di Kota Probolinggo. Jurnal IImu Lingkungan, 11(2), 100-109.

15. Singh, S., Haberl, R., Moog, O., Shrestha, R.R., Shrestha, P., \& Shrestha, R. (2009). Performance of an anaerobic baffled reactor and hybrid constructed wetland treating high-strength wastewater in Nepal-a model for DEWATS. Ecological Engineering, 35 (2009), 654-660.

16. Panambunan, T.N.P., Umboh, J.M.L., \& Sumampouw, O.J. (2017). Efektifitas instalasi pengolahan air limbah komunal domestik berdasarkan parameter kimia dan bakteri total coliform di Kelurahan Malendeng Kota Manado. Media Kesehatan, 9(3), 1-8.

17. Kementerian Negara Lingkungan Hidup. (2010). Peraturan Menteri Negara Lingkungan Hidup No. 01 tahun 2010 tentang Tata Laksana Pengendalian Pencemaran Air.

18. Kementerian Lingkungan Hidup dan Kehutanan. (2016). Peraturan Menteri Lingkungan Hidup dan Kehutanan Republik Indonesia Nomor: p.68/menlhk/setjen/ kum.1/8/2016 tentang Baku Mutu Air Limbah Domestik.

19. Dinas Lingkungan Hidup Kota Bogor. (2016). Laporan Akhir Pengujian Kualitas Air Limbah Sanimas Tahun 2016. Bogor: Dinas Lingkungan Hidup.

20. Dinas Lingkungan Hidup Kota Bogor. (2017). Laporan Akhir Pengujian Kualitas Air Limbah Sanimas Tahun 2017. Bogor: Dinas Lingkungan Hidup.

21. Kelompok Swadaya Masyarakat Cipendek Indah. (2015). Laporan Final Perkembangan Pembangunan House Connections of Sanimas' Communal IPAL in Kelurahan Bubulak, Kecamatan Bogor Barat, Kota Bogor, West Java. Bogor: KSM Cipendek Indah.

22. Azizah, R., \& Wibowo, A.A. (2013). Sanitasi ekologis IPAL sanimas di Kampung Sangkrah Surakarta. Sinektika, 13(1), 19-23.

23. Sumantri, A., \& Cordova, M.R. (2011). Dampak limbah domestik perumahan skala kecil terhadap kualitas air ekosistem penerimanya dan dampaknya terhadap kesehatan masyarakat. JPSL, 1(2), 127-134.

24. Romayanto, M.E.W., Wiryanto, \& Sajidan. (2006). Pengolahan limbah domestik dengan aerasi dan penambahan bakteri Pseudomonas putida. Bioteknologi, 3(2), 4249. 
25. Yudo, S., \& Said, N.I. (2018). Status kualitas air Sungai Ciliwung di wilayah DKI Jakarta, studi kasus: pemasangan stasiun online monitoring kualitas air di segmen Kelapa Dua - Masjid Istiqlal. Jurnal Teknologi Lingkungan, 19(1), 13-22.

26. Rizki, N., Sutrisno, E., \& Sumiyati, S. (2015). Penurunan konsentrasi COD dan TSS pada limbah cair tahu dengan teknologi kolam (pond) - biofilm menggunakan media biofilter jaring ikan dan bioball. Jurnal Teknik Lingkungan, 4(1), 1-9.

27. Soetopo, R.S., Purwati, S., Setiawan, Y., \& Adhytia, K. (2011). Efektivitas proses kontinyu digestasi anaerobik dua tahap pada pengolahan lumpur biologi industri kertas. Jurnal Riset Industri, V(2), 131-142.

28. Said, N.I. (2000). Teknologi pengolahan air limbah dengan proses biofilm tercelup. Jurnal Teknologi Lingkungan, 1(2), 101-113.

29. Wagiman, \& Suryandono, A. (2006). A tofu wastewater treatment with a combination of anaerobic baffled reactor and activated sludge system. Agritech, 26(1), 39-43.

30. Doraja, P.H., Shovitri, M., \& Kuswytasari, N.S. (2012). Biodegradasi limbah domestik dengan menggunakan inokulum alamid tangki septik. Jurnal Sains dan Seni ITS, 1(1), 44-47.

31. Nugroho, R., \& Yudo, S. (2014). Petunjuk Operasional Instalasi Pengolahan Air Limbah "Pt. Kinocare Era Kosmetindo". Jakarta: BPPT Press.

32. Budiyono, Khaerunnisa, G., \& Rahmawati, I. (2013). Pengaruh pH dan rasio COD:N terhadap produksi biogas dengan bahan baku limbah industri alkohol (Ninasse). Eksergi, 11(1), 1-6.

33. Yudo, S. (2010). Kondisi kualitas air sungai Ciliwung di wilayah DKI Jakarta ditinjau dari parameter organik, amoniak, fosfat, deterjen, dan bakteri coli. JAI, 6(1), 34-42.

34. Mustami, R., Ainun, S., \& Hartati, E. (2015). Karakteristik substrat dalam proses anaerob menggunakan biodigester. Jurnal Reka Lingkungan, 2(3), 1-12.
35. Indriyati. (2007). Unjuk kerja reaktor anaerob lekat diam terendam dengan media penyangga potongan bambu. J. Tek. Ling., 8(3), 217-222.

36. Sulihingtyas, W.D., Suyasa, I.W.B, \& Wahyuni, N.M.I. (2010). Efektivitas sistem pengolahan instalasi pengolahan air limbah suwung Denpasar terhadap kadar BOD, COD, dan Amonia. Jurnal Kimia, 4(2), 141148.

37. Dewi, N.L.P.M., Mahendra, M.S., \& Suyasa, I.W.B. (2014). Pengembangan fitoremediasi untuk meningkatkan kualitas air limbah hasil pengolahan instalasi pengolahan air limbah suwung. Ecotrophic, 8(1), 54-61.

38. Herlambang, A., \& Marsidi, R. (2003). Proses denitrifikasi dengan sistem biofilter untuk pengolahan air limbah yang mengandung nitrat. J. Tek. Ling., 4(1), 4655.

39. Harahap, S. (2013). Pencemaran perairan akibat kadar amoniak yang tinggi dari limbah cair industri tempe. Jurnal Akuatika, IV(2), 183-194.

40. Wahyuni, N.M.I., Suyasa, I.W.B., \& Mahardika, I.G. (2014). Efektivitas sistem biofilter aerob dalam menurunkan kadar amonia pada air limbah. Ecotrophic, 8(1), 79-85.

41. Supriyadi, D.B., \& Karnaningroem, N. (2014). Kinerja sistem instalasi pengolahan air limbah dengan seri unit anaerobic baffled reactor $(A B R)$ dan anaerobic fileter pada rusunawa. Proceeding Seminar Nasional Teknologi Praktis dalam Upaya Konservasi Air dan Energi, Teknik Lingkungan ULM, 9298.

42. Widodo, B., Andik, Y., Silvia, U., \& Ribut, L. (2009). Evaluation of decentralized communal wastewater treatment in Yogyakarta. 1st International Conference on Rehabilitation and Maintenance in Civil Engineering (ICRMCE). 
